\title{
Othering Racialised Femininity in Hip-Hop Journalism
}

\author{
DR. BARBARA ANNA PANUZZO, London South Bank University
}

\begin{abstract}
This paper investigates the gender and racial traits of female performative identity in hip-hop journalism. This is achieved through an evaluation of the editorial strategies that inform hiphop femininity in relation to the commercial agendas of the artists and the record companies and management teams behind them. This paper demonstrates that the editorial and artistic agendas that inform the hip-hop press produce gender and race-specific discourses which Other female hip-hop artists. The methodological approach to the research utilises discourse analysis to investigate narrative texts and images in selected US hip-hop magazines, and qualitative interviews with their main editors and journalists. The analysis indicates that articulations of identity in hip-hop journalism seem rooted in the fetishisation of the Black female body - a strategy of Othering that paradoxically possesses a counter-hegemonic value in its resistant approach to normative gender and race discourses. The journalistic mediations of hip-hop womanhood present, therefore, some of the socio-cultural challenges posed by hip-hop feminism, such as the double jeopardy of the assertive reclamation of female sexuality and the compliance with race-specific sexist discourse. Moreover, this paper shows that notions of gender and race mediated by the hip-hop press are commercially driven, as they appear to be informed by interdependent financial interests of artists, press and record industries. In this context, an important insight is that female artists appear to be complicit in their own Othering through the production of mediated performative identities which undermine their position as authentic performers.
\end{abstract}

\section{KEYWORDS}

Hip-Hop; Race; Gender; Journalism; Identity

\section{Introduction}

The normative gender and racial positioning that relegates women to the role of hip-hop's second class citizens is evident within the hip-hop press as well as the more critiqued media output of hip-hop culture, such as music and video performance. The intersections of gender and race discourses in the mediation of female hip-hop performative identities will be explored in the first section of this paper. My analysis draws on a culturally-situated, Butlerian notion of performativity, intended as the 'reiterative power of discourse to produce the phenomena that it regulates and constrains' (Butler 1993, 2). As performativity comprises the range of socio-cultural discourses that it stages, it functions as a situated practice which feeds from and into the context within which it is placed. In the context of female hip-hop performative identities, the issue of the subject's agency becomes problematic as it demonstrates an ability to appropriate and communicate already existing cultural discourses. Although the involvement of female performers with the mediation of their femininities is an aspect often debated academically in the context of rap music and video production (Pough 
2004; Rose 2008; Sharpley-Whiting 2007), it is rarely investigated within the texts of hip-hop journalism (Cepeda 2004; Wang 2006).

In the second section of this paper, I analyse a range of textual and visual representations of female hip-hop performers in US hip-hop press articles. The selection ranges from mainstream contemporary press to digital publications, in order to account for the evolution of hip-hop journalism over the years. This analysis is compounded, in the final section of the article, by discourse analysis of qualitative interviews conducted with experienced editors and journalists working for hip-hop magazines. The study reveals that the media space that female artists occupy in the hip-hop press is scarce and hyper-sexualised. The relevance and quality of editorial content, as well as of the roles performed by female artists within its production, indicates a lack of dynamicity in female coverage. Nonetheless, I argue that this very limitation is significant as it points to the existence of underlying editorial and marketing agendas which are part of the gender gate-keeping practices regulating the hip-hop press.

\section{Hip-Hop Femininities: the Gender/Race Nexus}

The gender and racial nexus of hip-hop performative identities, a central theme of hip-hop scholarship, is largely contextualised within the prerogatives of the Black American public sphere (Kitwana 2005; Rose 1994; Sharpley-Whiting 2007). In relation to hip-hop womanhood, this appears to alienate a large portion of an ethnically-diverse audience who use hip-hop to make sense of a specific discourse of gendered identity. Consequently, I claim that the theoretical perspectives of the performative discourses of race and gender in hip-hop would benefit from a cohesive approach. This paper aims, therefore, to review the journalistic portrayals of hip-hop female performative identities from this perspective. The research carried out demonstrates that the cultural momentum of hip-hop's racial engagement presents generally regressive gender roles, as it is largely based on an essentialist (Black) masculine identity.

The strategies of engenderment that hip-hop performers appropriate for themselves appear to be more directly connected to their racial identity, as evidenced by the ethnic grounding of the Strong Black Woman performative variants, which historically present a characteristic of invulnerability to this specific conflation of female gender and Black ethnicity (BeauboeufLafontant 2009). This racial posturing has been the focus of most hip-hop academic analyses (Morgan 1999; Pough 2004; Sharpley-Whiting 2007). Approaching the gender-race liaison from a gender perspective is therefore more challenging, as female hip-hop performers appear to make sense of their gendered identity from a racial viewpoint, yet rarely perform their ethnicity as gender-specific. Whilst the double jeopardy of Blackness and womanhood is often called into question, little attention is paid to understanding how women in hip-hop interpret their ethnicity, not necessarily just in terms of Blackness, but also in relation to their gender. The gender and race dynamics of hip-hop are informed by a Black masculine domination of the cultural space, which subsequently forces women to occupy a counterhegemonic position. In turn, this functions not only as a discourse of resistance, but also as one of validation (Forman 2002; Richardson 2006; Rose 1994).

In this respect, the discourse of Blackness in hip-hop seems to dilute the importance of gender dynamics because of the united front that Black males and females are expected to present to fend off the threat of White cultural banditry. Therefore, Black female performers, generally demeaned by fellow Black male artists on record and in videos, are valued as allies in this perceived battle and, as such, are expected to renounce the fight against gender 
discrimination to provide their support in the name of ethnic strength (Kitwana 2005; Rose 2008). At the same time, hip-hop femininity is understood from a limited racial positioning that perceives Blackness as the authentic ethnicity. However, I argue that the relevance of race within the understanding, organisation and negotiation of gendered identity should not be summoned as a simplistic justification to hip-hop femininity, but it should rather be approached from a post-structuralist perspective.

The complex process of engendering identity through racial specificity is integral to the discourses that female hip-hop artists employ in order to characterise their femininity in racial terms. In light of this, it is important to analyse the way they utilise specific racial traits, at times through over-emphasis, to convey the ethnicity of their gender. This strategy acquires relevance when deployed in a cultural environment such as hip-hop, which is overcrowded with images of Blackness that are, for the most part, male-fashioned. Black women who use hip-hop to speak about, for and to the hip-hop community do embrace the burden of representation of their gender and race as a tactic to disrupt existing discursive formations. This means, however, that Black female performers engage with hip-hop using a limited variety of stylised subject positions. These appear to be commonly accepted as representative of a racial Othering of women, as will be shown in the analysis of press portrayals in this paper.

\section{Femininities in the Hip-Hop Press}

Despite the widely recognised success of early female rappers such as Lil' Kim and Foxy Brown, their appearance on the front covers of hip-hop magazines appears to be rare. Even the Village Voice, originally heavily focused on providing media coverage of the rapid development of hip-hop culture, seldom allocates significant space to female hip-hop performers. It is not until much later in the 2000s that female hip-hop artists are given significant editorial relevance in this publication, moving up from generic music reviews to in-depth cover stories such as the October 2007 feature on female rapper Remy Ma, which is supported by a dedicated front cover (Village Voice 2007). This shows a three-quarter-length picture of Remy Ma holding a tag with the magazine's logo above her head. The artist wears a simple black body suit which sets off her curvaceous body frame, and is heavily accessorised by several gold bangles and a large golden chain with a pendant representing the head of an African woman. The picture captures Remy Ma's performative image of a sophisticated Black woman with attitude, whose attire is reminiscent of hip-hop's old school uniform of fashionable clothing and oversized accessories, while also pointing at her ethnic heritage (Morgan, 1999). The feature provides an account of Remy Ma's career, and includes extracts from an interview from which a number of clichéd references to her felonious past, her flashy home, and her masculine posturing emerge. Arguably, such discourses serve to mythologise Black female hip-hop identity by inverting normative gender dynamics to establish what Sharpley-Whiting defines as 'Black female masculinity', that is, a performance of identity that Others Black women as the 'new niggaz' (Sharpley-Whiting 2007, 144).

The increasingly public presence of female performers brought on by the commercial success of hip-hop in the early 2000s reputedly indicates a higher demand for magazine coverage. The quality of coverage of female artists in the hip-hop press adapts to this trend, as the front covers of print and digital magazines evolve from a stylistic perspective to project a sense of three-dimensional portrayal of the artists they promote. Erykah Badu's front cover appearing in a print and digital issue of Rap Pages (2010a) is, for instance, a simple yet captivating 
portrait of the artist which also visually conveys key aspects of her identity. In this picture, Erykah Badu's symbolic embrace of ethnic attire, combined with the adoption of a public speaker pose in front of a long stem microphone, can be read as a representation of her ethnic-centred, prophetic stage persona. The discourse of hip-hop femininity visually performed here sits on the opposite spectrum of what Sharpley-Whiting refers to as 'ethnically ambiguous' (Sharpley-Whiting 2007). With the sense of agentive assertion it exudes, this portrayal is, in fact, more in line with Morgan's 'STRONGBLACKWOMAN' stance, which defines an empowering gender/race nexus of hip-hop femininity (Morgan 1999). However, the iconoclastic use of photography in this cover is accompanied by the removal of the artist's name. Here, the artist's identity is excribed by its iconic symbolism, thus rendering the exclusion of her name as a further strategy of her Othering.

The iconic front cover style of Rap Pages, which makes use of high-impact visual references to increase the collectable value of the magazine, is also evident in the October 2010 pictorial portrayal of ubiquitous female rapper and singer Nicki Minaj (Rap Pages 2010b). This is a playful rendering of the artist's stage identity, strongly evocative of her Black Barbie doll performative position (an image pioneered by Lil' Kim) which is complemented by the orange dyed hair and provocatively tight-fitting, see-through outfit. Although her femininity is exalted in the curve-enhancing pose, the slight part of the lips and the sophisticated makeup, the lasciviousness of this look is contrasted by the closing of one of her hands into a fist adorned by a gold knuckleduster. This, I argue, functions as a symbol of dynamic aggression, and implies a discourse of gendered power in line with its post-structuralist rebuttal of essential femininity. The fragmentation of the image into body parts or props that signify discourses of femininity is widely evidenced in hip-hop magazines front covers. Here, the reliance on the use of symbolic imagery to portray female artists on the covers of Rap Pages can be interpreted as a strategy of 'excription': an outer inscription of the body that Others its image (Nancy 1992, 14).

More recently, Village Voice published an innovative joint opinion piece on Nicki Minaj's debut album (Baron and Juzwiak 2010). The article, accessed on the publication's digital format, is underscored by an iconoclastic portrait of the artist that combines a range of cultural references from Japanese warriors to (Black) Barbie dolls. The close-up of Nicki Minaj's face is a pastiche of several of the rapper's defining performative traits. Her focused gaze, looking directly at the spectator through the camera, is framed by a tightly curled mane of orange-blonde hair and underscored by abundant pink-toned make-up. Her eye make-up adds an ethnic theme to the image by tilting the artist's eyes upwards to create the suggestion of oriental facial features, significantly Othering her racial positioning towards the hues of Sharpley-Whiting's 'ethnic ambiguity' (2007). Nicki Minaj wears a pink outfit, accessorised by a pearl and diamond choker necklace which directly draws the reader's attention to her generously exposed chest, the prominence of which she often utilises as a trademark of her identity. In her hands is a half-opened Japanese sword with a pink handle, which contributes to create a sense of incongruence in the juxtaposition of the serene concentration of a Japanese martial artist's look with the hyper-feminine traits of a performing Black Barbie doll. The sword is positioned between her face and her pronounced cleavage, thus framing her breasts as a visual signifier of sexual desire whilst drawing attention to her facial expression. In this context, the sword can symbolise the danger of emasculation, which generates a fetishism of her gazed racialised femininity by producing a fear of castration. The evident use in this picture of post-production techniques to enhance the vibrancy and contrast of the colours, as well as to place the artist against an abstract digital background, also helps create a sense of Othering assembly. Here, the image references a hyper-reality that is 
simulated and, therefore, its value is ideological rather than directly connected to the physicality of the subject (Sutton 2007). The assembled image with its focus on the Japanese sword functions as a symbolic sign of strength; in the context of the patriarchal discourses reproduced within hip-hop journalism, Nicki Minaj appears, therefore, to subvert hegemonic gendered positions.

Nicki Minaj's performance of gendered identity innovatively proposes a resistant appropriation of the normalising imagery circulated within hip-hop. Her embracing of stylised gender and race tropes functions as a strategy to subvert flat stereotypes into artificial simulations. This indicates her intent to humanise the Black Barbie doll imagery in a way that challenges traditional racial signifiers such as hair colour, skin complexion and body shape. Such a performative strategy appears to work as an attempt to combine creatively the normative standards of White beauty, exemplified in a Barbie doll representation that visualises a dominant representation of Black femininity. I argue that the merging of these gender and race discourses creates an innovative discourse in itself, which consists of an original take on the mediation of ethnic ambiguity that functions as a tool of performative resistance of the very same discourses it stems from. Nonetheless, in so doing, Nicki Minaj seems to also amplify the visual Othering of a Black skin fetish. Drawing from Mercer's analysis of the visual reproduction of racial fetishism within photography, the assembled, symbolic imagery mediated by Nicki Minaj can be interpreted as 'a cultural artefact that says something about certain ways in which White people "look" at Black people' (Mercer 1999, 435). Nicki Minaj's Othered press mediation, when approached from Mercer's perspective, suggests the existence of underlying racial editorial strategies which will be addressed further in this paper.

A number of more niche hip-hop magazines emerging from the late 1990s to the mid-2000s also produced interesting narrative and visual content on female performers. For instance, One World, Russell Simmons' short-lived attempt at providing an intellectual journalistic approach to hip-hop culture, dedicated a front cover and editorial spread to female rapper Lil' Kim in its January 2003 issue. The controversy generated by the front cover picture, which depicted an almost-naked shot of the artist wearing a burka, significantly overshadowed the context of the editorial feature itself. This cover stirred a wave of dissent against both Lil' Kim and Russell Simmons, as it was largely perceived to be a direct insult to the sacred female body as defined by Islam. The association of the traditional Muslim female headgear with Lil' Kim's exposed body was intended as a provocative statement against hegemonic notions of female respectability, as explicitly explained by the artist in subsequent interviews (Rapdirt 2002). This displays an advanced level of agency on the artist's part over the discourse mediated through the image. It also hints at an awareness of the strategic use of controversy within a journalistic environment, which is characteristic of the hip-hop press (McLeod 2002). This image of Lil' Kim, made exotic by the burka, Others her ethnic positioning by deconstructing her Black female body to produce desire, in line with media paradigms of male heterosexual consumption. The religious overtone of the visual execution is used here as a hook to attract controversial attention to the artist (and the magazine) in the context of post-9/11 American imperialism, where the burka is deployed, I argue, as a symbol of exotic fetishisation.

This strategy of visual orientalism, merged with the nakedness of the Black female body, renders Lil' Kim sexually desirable and, as such, a commodity for record and magazine sales. Lil' Kim's deconstructed body Others her gendered and racial identity, yet it produces a hyper-exotic fetish which makes it desirable rather than repulsive to the male patriarchal 
consumers. The semi-political statement made by the incongruous appropriation of an extremely gendered item of clothing, the burka, is peculiarly reclaimed in the challenging context of her nudity and the camera angle that forces the viewer to look up to her, thereby increasing her importance, to create an altogether different meaning of female empowerment. This functions as a performative strategy largely embraced by the artist in her quest to assess alternative ideals of femininity impinged on women's right to sexual freedom.

A distinctly oppositional approach to the editorial treatment of female hip-hop artists so far analysed is deployed by Downlow magazine, in which pictures of women frequently appear on the front covers. The majority of these artists are, however, video vixens who are mostly used as props within the front covers, often in a disjointed manner, to glorify the male rappers to whom the space is dedicated. In these shots, women are scantily clad and adopting almost $\mathrm{x}$-rated poses, sitting on the border between music journalism and adult entertainment. The politics of male heterosexual desire that contextualise these images produce female identities that are gazed at from a specific racial perspective. The affect of the mediated male gaze on Black female bodies is discussed by bell hooks (1992), who reflects on the ways in which contemporary popular music mediates a gazed portrayal of Black women's 'butts' by turning them into a symbolic fetish of Black females' perceived hyper-sexuality. In this context, the gaze is responsible for the mutilation of Black female bodies and the simultaneous reinforcement of racial and gender normative imagery, as evident in the insistent portrayal of women's backsides in hip-hop music and videos. Drawing on Grayson and Schulman (2000), the discursive deconstruction of Black female identity into fetishised body parts, as evidenced in many Downlow covers, functions as an index for a discourse of masculine desire. As Mercer (1999) explains,

The image of the female nude can thus be understood not so much as a representation of (hetero)sexual desire, but as a form of objectification which articulates masculine hegemony and dominance over the very apparatus of representation itself (417).

Although Mercer focuses her analysis on the relationship between Black racial fetish and White male gaze, I argue that the inclusion of male rappers of various ethnicities in those pictures is indicative of a gendering of the gaze that is more prominent than its racialising. The eroticised look of the almost nude female body, presented through post-colonial hegemonic signifiers of Black female sexuality, functions as a strategic gender Othering at the hands of the male gazers, regardless of their ethnicity.

\section{Editorial Strategies of Supply and Demand}

The coverage of female hip-hop performers in print and digital publications that emerged from this research is scarce, superficial and over-sexualised. While female artists have reclaimed their territory on stage, in academic critique and in the media, they appear to have largely been featured in dime-piece sections of hip-hop magazines. In this context, the dimepiece label refers to the urban appellative of attractive female. These sections offer, in fact, brief, mainly pictorial coverage of beautiful, scantily-clad female artists. The general view of the twenty-two editors and journalists interviewed in this research, who prefer not to be identified by their real names, is that not enough female artists have been considered worthy of journalistic coverage. This discourse is further complicated by the strategic visual mediation of female sexuality in the pages of hip-hop magazines. To illustrate this point, I draw from the insights shared by Anthony, Editor-in-Chief of an established hip-hop 
magazine, who claims that 'without sexuality a magazine has a hard time in hip-hop' (Anthony 2009, 2).

Drawing on Frith (2002), I argue that the vested interest of record companies in the promotion of their artists via the hip-hop press plays a role in the editorial approach to the level and type of female artists' coverage. However, all the record company executives approached for research purposes refused to be interviewed on this topic. Such editorial vision is not specific to the hip-hop press, as the connection between generous displays of female physical beauty and increasing sales and page viewings is largely observed within the wider media landscape (Eldridge 2009; Gill 2008). Joseph, an experienced hip-hop journalist interviewed in this study, presents, however, a different point of view, as he comments on the editorial strategies behind the selection of artists for covers and features:

Relevance, timing, popularity, sales... those are probably the biggest factors along with one of the big ones: being the first to 'blow up' an artist by putting them on a cover (Joseph 2010, 1).

The variables cited by Joseph as informing his editorial vision are common to the strategies deployed in the wider music press, where editors function as leaders of public taste (Frith 1981) and intermediaries between record companies and audiences (Negus 1999). However, the dexterity of female artists is inherently Othered in relation to their fellow male rappers in a way that precludes them from setting their own industry-wide standards. Maria, the Founder and Editor-in-Chief of one of hip-hop's longest-standing magazines, describes in an interview a seeming absence of gender politics in the editorial strategy behind hip-hop artists' coverage:

We write about who people wanna read about [...]. It's not about the gender but more about, you know, do people care about this artist? And, unfortunately, you know, there's not that many female artists that people wanna read about (Maria 2010, 7).

Maria's words illustrate her belief in a demand/supply mechanism which justifies gender discrimination within hip-hop journalism. My argument here is that such presuppositions with regards to the audience's taste are a consequence, rather than a justification, of gendered editorial policies already in existence within the hip-hop press. Moreover, the lack of interest in providing editorial coverage of female artists as musicians, which is in contrast to an editorial predilection for eye-grabbing body shots observed in the hip-hop press, suggests that the objectification of the female body is commercially driven. Whilst the lack of female artists' written coverage is neatly explained by the need to cater to the audience's politics of male sexual desire, the same motivation is given to justify the editorial use of over-sexualised female imagery. This is apparent in the widely accepted use of female imagery that borders on the pornographic across dime-piece features such as, for instance, Ozone magazine's popular 'Dollar Menu'. These brief articles propose a professional perspective on the lives of hip-hop video vixens, despite being accompanied by often uncensored booty shots. Therefore, the combination of sexually allusive imagery and brief, yet insightful written content is adopted as an ethical bargaining tool which does not address the fundamental objectification of women on the basis of a gendered and racialised process of Othering. Adam, a veteran US hip-hop journalist interviewed in this project, offers further insight into the relationship between editorial approach to female hip-hop artists and the specific marketing strategies that support them commercially: 
Female artists, like male artists as well, have their image shaped and pushed by the people up in record labels [...]. I don't necessarily see the editorial side of things trying to sex-up a female artist any more so than what she's doing or what her label is doing on her behalf (Adam 2010, 4).

This emerging editorial strategy hinges on the concept devised and promoted by the particular artist or record company. It is important to note that, according to Adam, the editorial focus of the feature tends to adapt to the wider marketing concept rather than offering a neutral portrayal of the artist. In the case of artists such as Lil' Kim, whose performative identity is built on sexual empowerment, the journalistic mediation of visual and textual hyper-sexuality take the form of a mere extension of the marketing machine behind her.

Within the sample of publications reviewed here, the visual portrayal of female hip-hop artists appears to be a carefully constructed mediation of a specific concept of performative identity masterminded by the artist, the record company and the press, in order to benefit album and magazine sales. However, magazine front covers are also deployed as tools to validate the relationship between the artist and the press, sometimes through the use of tactical controversy. This is exemplified in the 1999 front cover of VIBE, graced by a picture of rapper Foxy Brown in a skimpy bikini, with the caption 'Sex Sells and Rhyme Pays so Foxy Brown Wants to Know What's Wrong with Being Strong?' (Smith 1999, 112). The artist was so upset with the cover picture, headline and story that she later physically assaulted Smith (VIBE Books 2001). At a time when Foxy Brown had carved her niche in the reputedly sexist context of hip-hop, the cover sent a clear message about the role of females, as it identified the artist as a woman whose strength is legitimised by the power of sexuality, thus shifting the focus away from her rapping skills. In order to be paid her dues as a competent female rapper, the headline suggests, Foxy Brown has to use her sexualised performative identity as currency.

The picture chosen for this front cover, which showed the artist grabbing her breast with one hand and her crotch with the other, visually supported this lyric commoditisation of the Strong Black Woman. The feminist reclamation of the 'bitch' identity (Morgan 1999; Sharpley-Whiting 2007) seems instrumental in defining the role of women in hip-hop, and it encompasses a range of attributes that are largely perceived as a justification for the success of female artists. Further on in the article, Smith urges Foxy, and all female readers, to "be nasty. Be classy. Be extravagant. Be everybody's fantasy. Hey, soul sister! Be superstrong, supersexy, supertalented, supersatisified. Be supergirl' (Smith 1999, 116). Smith captures here the inherent contradiction of female hip-hop performativity, caught by the double-edged sword often described by Pough (2004), Morgan (1999) and Sharpley-Whiting (2007) of embracing hyper-sexuality as an objectifying, yet simultaneously resistant discourse. Whether skilled female artists grapple with masculine posturing or with over-sexualised performances to be granted professional recognition, there is no denying that the female hiphop performative identity is a complex and intrinsically conflicting one.

Hip-hop journalism, like most contemporary media channels, has undergone several technological and stylistic changes that have affected the peaks and troughs in its mainstream impact on hip-hop culture. The rigour and depth of content that characterised the original tenet of hip-hop journalism is sacrificed in favour of accessibility to a significant volume of content, in a real-time frame (Wang 2006). This stylistic decline of the hip-hop press is even more evident when observing the scarcity of quality journalistic coverage of female artists, as 
emerging from this research. When attempting to pinpoint the editorial strategies which have motivated this shift, three recurrent themes emerge: the comparative lack of 'worthy' female artists, the hetero-normative positioning of the artist (enabled by the artist, the record company, and/or the wider editorial vision), and the perception of the audience's taste (based on its racial makeup). Andrew, Editor-in-Chief of a contemporary underground hip-hop title, addresses the latter when interviewed for this research:

It's a certain type of female artist that is going to appeal to the core audience. [...] And hip-hop, [...] while it is mostly African-American music, seventy percent of the buying public are still White Caucasian. So, nonetheless, their tastes will dictate to a degree exactly what winds up in the magazine. And I think what you're seeing appear in the magazines is a reflection of what both the editors think their audience want, and what the writers think the editors want (Andrew 2010, 4).

According to Andrew, the editorial interpretation of the gender and racial makeup of hiphop's primary audience appears to be directly connected to the journalistic coverage of artists. In a telephone interview, Editor-in-Chief Maria points out that the gender of the writer can also be taken into account when pursuing a specific editorial perspective in a story. This becomes apparent in the way an editor can use their gendered perspective to inform the magazine's editorial vision:

I think we have a higher percentage of female readers than some other magazines, and that probably just stems from the fact that, you know, I am a female and it is my publication, it is my own show. I think in a lot of the interviews I do, the kind of questions I ask are not necessarily something a guy would think of, but more what a female would want, just because I am a female (Maria 2010, 4).

Maria firmly believes in the influence of her own gender in terms of increased appeal towards readers of the same sex. She substantiates this claim by citing the feminine tuning of her interview style, which emerges as a tendency to ask questions from a marked gendered position. When flicking through the pages of her magazine, however, evidence of this is mostly found in the regular editorial feature dedicated to video vixens and female porn stars affiliated with hip-hop, whose coverage does not exclusively focus on their hyper-sexual performative identity, but proposes empathic insight into these women's lives. Here, I draw on Mulvey (1975), who proposes that the only way for females to acquire a gaze of their own is to appropriate the role of the hegemonic male gazer (or, in this case, reader) and objectify the gazed subjects in the same manner as the male gazer does. A disturbing implication of this dynamic is, however, the semantic reduction of the female gaze as an Othered alternative to the normative male gaze, which ultimately points to a complicit renouncement of female agency in the mediation of hip-hop gendered performativity.

In this context, the recurrent presence of female editorial staff in mainstream hip-hop magazines is, perhaps ironically, indicative of deep-seated discrimination that produces the derogatory portrayal of female artists. Jane, an established hip-hop journalist and Editor, adds further insight into this discussion by placing the adoption of a male gaze as the lead editorial vision, even if edited by female staff, in direct correlation with the fast-tracking of these journalists' careers. She argues, however, that the ethnic identification of women who hold a position of power within the hip-hop press industry explains, to an extent, the tolerance and mediated perpetuation of these gender double-standards: 
But there is a group of white critics who love the most ignorant rap they can find; they've built careers around it. I sometimes wonder if perhaps their comfort level with the types of depictions of Black and Latino women and Black and Latino men has to do with the fact that it's not really about them (Jane 2010, 13).

I partially agree with Jane's weighting of racial identification in the gender politics mediated by hip-hop journalism. Being a White woman could indeed create an alleged detachment from the discriminating imagery and narrative content used to portray Black females. However, I argue that, in light of the deeply set commercial concerns that fuel the hip-hop press, the racial and gender makeup of the journalistic staff has limited bearing on the determination of the overarching editorial strategies operating on the gender mediation. Hiphop culture was, and still is, not only commercially co-opted, but also genuinely enjoyed and actively contributed to by non-Black individuals holding positions of power. In light of this, it appears necessary to interrogate the position of the artists and record companies who package and promote these Black female performative identities that range from the regressive to the revolutionary. The reference to the large number of female journalists employed within the hip-hop press seems to increase a sense of antagonism towards hip-hop feminism and its spokespeople. Jane shows a keen awareness of the editorial politics at play in this environment, highlighting that hip-hop feminism is hardly a united front in this mediated space:

We're not operating in a place where all women are feminist avengers. We're operating in a context where a lot of women behave in problematic ways, either with other women in and around the industry, or with men. That makes it a murkier environment (Jane 2010, 13).

Jane highlights here the existence of fractious behaviour amongst female journalists, which, in turn, reinforces the already precarious gender positioning of females within hip-hop. Jane also recognises that a similar trend characterises hip-hop performance, where female artists either refute the feminist label or embrace it despite using male crews to establish their presence in the industry. In light of the contradictions which underpin women's engagement with hip-hop, whether as artists, writers or editors, the fields of hip-hop performance and its journalistic documentation appear to thrive on the mediation of implicitly conflicting gender discourses and racial connotations.

By reclaiming agency via hip-hop performance, women situate particular discourses of semiotic identity within a cultural arena rife with stereotypes of gender and race. As demonstrated in this research, the articulation of female performative identity is a crafted representation, yet one that is embedded in collective cultural mythology and perpetuated in the mediation to its consumers. Women's role in hip-hop is also defined by our own consumption of primary products of hip-hop culture, as well as the wider public sphere, which includes hegemonic beauty culture, masculine posturing, heterosexuality and misogyny (Morgan 1999). From a racial perspective, the narrowing standards of Black beauty, which is still the cultural signifier used by both performers and audiences to attribute primary visual value to hip-hop femininity, appear to be ultimately waged on a hierarchy of hegemonic Whiteness (Richardson 2006; Sharpley-Whiting 2007). This is particularly troubling given the range of Black identities, as the embracing of typically Black attributes of beauty becomes in itself a strategy of Othering, where hip-hop and mainstream culture meet in the middle of ethnic fetishism. 
By appropriating a male patois in their performances of identity, female hip-hop artists mediate the inherent conflict of the Strong Black Woman, whose strengths and weaknesses are Othered in male-influenced hues (Morgan 1999). Such imagery is reproduced in a variety of performative types which highlight the link between the patriarchal vision of the hip-hop woman and the consequent production of female stereotypes. Hip-hop femininities are depicted as prey to the double jeopardy of the gender/race nexus in their bid to promote Black manhood, yet they simultaneously vindicate the necessity of the ride-or-die ('there for your man no matter what') womanhood against misrepresentation. This demonstrates how Black women in hip-hop position their identity dialogically in relation to the opposite gender, making it, perhaps, more difficult to define an independent, proactive notion of femininity. This trend is exacerbated by the misconception that an overt feminist embracing of hip-hop equates to the surrender of the power that lies in the racial bond between Black males and females (Morgan 1999; Pough 2004; Sharpley-Whiting 2007). I argue, however, that the empowering position of the Strong Black Woman could be reconciled with a feminist agenda in order for women in hip-hop to overcome the impasse of gendered and racialised stereotyping. The progressive effort of hip-hop feminism to approach gender and race as contextual notions could finally ease the knot of the intra-racial bond that constricts gendered identities within hip-hop.

The way in which editors and journalists portray women in hip-hop magazines presents hiphop audiences with specific racial, sexual and gender traits. According to Sharpley-Whiting (2007), mainstream hip-hop journalism approaches Black sexuality through a corporate formula of female desirability, which is negotiated in two mythologised positions: the hypersexualised, ethnically ambiguous (but still culturally signified Black) video vixen versus the androgynous, tom-boyish skilled rap artist. The subversive assertion of sexual agency on which female discourses of hip-hop performative identity are based and mediated through the pages of the hip-hop press, ironically appears to strengthen the objectification of female sexuality, while simultaneously functioning as a tool of female empowerment. For instance, the stereotyped figure of the 'bitch', with its array of visual and narrative nuances, seems to act as a paradox, disrupting fixed gender roles while it is, perhaps, also delusional. Although the aggressive reclamation of sexuality can be used as a tool for female emancipation, it is not free of stigma, as this discourse is presented as a form of Black masculinisation. Therefore, the journalistic portrayal of female hip-hop artists delineates the multifaceted contours of a woman who is Othered as a performer, while also being projected to the readers as authentic.

\section{Conclusions}

This paper has examined the editorial treatment of female hip-hop artists that emerged from their visual and narrative coverage in selected hip-hop magazines. Staple hip-hop press publications such as The Source, Vibe, and Rap Pages have offered an iconic display of multi-layered female performative positions in their print and digital pages. The interplay of descriptive and visual elements in these texts articulates discourses of hip-hop womanhood that range from the Bitch to the Strong Black Woman stances. The use of iconic photography, particularly in front covers, has emerged as a recurrent strategy which visualises power, which can strengthen the relationship between artist and media outlet through allegiance or controversy - a mutually beneficial result, as they both generate public interest.

Despite the rich variety of performative identities examined, a limited range of discourses of gender and race have emerged from this analysis. The objectification of the female body, 
mediated through symbolic imagery of sexualised assets, appears to be informed by the desire of the male gaze. Female artists appear to perform their identities through the mediation of normative gender and racial positions that are largely hyper-sexual. These performative discourses are often underscored by the use of shocking images which can be interpreted as attempts to counter normative gender tropes. In this context, the female body is objectified in terms of a racial-specific sexualisation which functions within the parameters of post-colonial hegemonic beauty standards. Although the female body is fetishised as Black, it also presents various degrees of ethnic ambiguity where the Black skin fetish becomes a hegemonic cultural artefact.

The gender-race nexus that is discursively mediated within hip-hop journalism is explained by the relationship between editorial production and audience consumption. The evidence gathered during the qualitative interviews with editorial staff indicates the existence of commercial pressures for the artists to subscribe to normative gendered and racialised positions. These discourses are further complicated by the agency that female artists display in the articulation and journalistic mediation of their performative identities. In turn, the agentive position of female artists in this context appears to be informed by the cultural pressure to deliver an Othered performance of gender and race, in order for their skills to be recognised as authentic and, therefore, worthy of journalistic coverage.

\section{References}

Adam (2010) Telephone interview by B. Panuzzo, 24.08.2010.

Andrew (2010) Telephone interview by B. Panuzzo, 18.06.2010.

Anthony (2009) Online interview by B. Panuzzo, 10.09.2009.

Baron, Z. and Juzwiak, R. (2010) 'Nicki Minaj's Pink Friday, Debated', The Village Voice, 24.11.2010, http://www.villagevoice.com/2010-11-24/music/nicki-minaj-s-pinkfriday-debated/ [accessed 04.09.2010].

Beauboeuf-Lafontant, T. (2009) Behind the Mask of the Strong Black Woman: Voice and the Embodiment of a Costly Performance, Philadelphia: Temple University Press.

Butler, J. (1993) Bodies That Matter. On the Discursive Limits of 'Sex', New York: Routledge.

Cepeda, R. (ed.) (2004) And It Don't Stop! The Best American Hip-hop Journalism of the Last 25 Years, New York: Faber and Faber.

Eldridge, A. (2009) 'Sex Sells: A Content Analysis of Women in Magazine Advertisement's, Senior Seminar, 485, Dan Cronn-Mills'. Available from: http://mavdisk.mnsu.edu/eldria/7A.htm [accessed 31.03.2012].

Forman, M. (2002) The 'Hood Comes First. Race, Space, and Place in Rap and Hiphop, Hanover: Wesleyan University Press. 
Frith, S. (1981) Sound Effects: Music, Leisure and the Politics of Rock'n'Roll, New York: Pantheon.

Frith, S. (2002) 'Fragments of a Sociology of Rock Criticism', in S. Jones (ed.) Pop Music and the Press, Philadelphia: Temple University Press (pp. 235-246).

Gill, R. (2008) 'Empowerment/Sexism: Figuring Female Sexual Agency in Contemporary Advertising', Feminism Psychology, 18, 1, 35-60.

Grayson K. and Schulman, D. (2000) 'Indexicality and the Verification Function of Irreplaceable Possessions: A Semiotic Analysis', Journal of Consumer Research, 27, 1, 17-30.

hooks, b. (1992) Black Looks: Race and Representation, New York: Routledge.

Jane (2010) Telephone interview by B. Panuzzo, 27.09.2010.

Joseph (2010) Online interview by B. Panuzzo, 14.11.2010.

Kitwana, B. (2005) Why White Kids Love Hip-hop. Wankstas, Wiggers, Wannabes, and the New Reality of Race in America, New York: Basic Civitas Books.

Maria (2010) Telephone interview by B. Panuzzo, 10.05.2010.

McLeod, K. (2002) 'The Politics and History of Hip-hop Journalism', in S. Jones (ed.) Pop Music and the Press, Philadelphia: Temple University Press.

Mercer, K. (1999) 'Reading Racial Fetishism: the Photographs of Robert Mapplethorpe', in J. Evans and S. Hall (eds.) Visual Culture: The Reader, London: Sage.

Morgan, J. (1999) When Chickenheads Come Home to Roost: My Life as a Hip-hop Feminist, New York: Simon and Schuster.

Mulvey, L. (1975) 'Visual Pleasure and Narrative Cinema', Screen, 16, 3, 16-18.

Nancy, J. (1992) Corpus, Paris: Editions Métaillés.

Negus, K. (1999) Music Genres and Corporate Cultures, London: Routledge.

One World (2003) 01.2003 Issue. Available from: http://lilkimfanclub.com/photo352.html [accessed 07.09.11].

Pough, G. D. (2004) Check It While I Wreck It: Black Womanhood, Hip-hop Culture and the Public Sphere, New York: Northeastern University Press.

Rapdirt (2002) 'Lil' Kim's Muslim Insulting One World Cover Under Fire'. Available from: http://rapdirt.com/lil-kims-muslim-insulting-one-world-cover-under-fire/3577 [accessed 07.09.2011]. 
Rap Pages (2010a) 04.2010 Issue, Online Volume 20. Available from: http://www.myspace.com/rappagesmagazine/photos/70511936\#\%7B\%22Imageld\% 22\%3A70511936\%7D [accessed 07.09.2011].

Rap Pages (2010b) 10.2010 Issue, Online Volume 26. Available from: http://s849.photobucket.com/user/RapPagesMagazine/media/Rap\%20Pages\%20Ma gazine\%20Covers/MinajCoverOct10.png.html?sort=3\&o=4 [accessed 07.09.2011].

Richardson, E. (2006) Hip-hop Literacies, New York: Routledge.

Rose, T. (1994) Black Noise. Black Music and Black Culture in Contemporary America, Hanover: Wesleyan University Press.

Rose, T. (2008) The Hip-hop Wars. What We Talk About When We Talk About Hiphop - and Why it Matters, New York: Basic Books.

Sharpley-Whiting, T.D. (2007) Pimps Up, Ho's Down. Hip-hop's Hold on Young Black Women, New York: University Press.

Smith, D. (1999) 'Sex Sells and Rhyme Pays so Foxy Brown Wants to Know What's Wrong with Being Strong', VIBE, December/January, 6:10 (112).

Sutton, D. (2007) 'Real Photography', in D. Sutton, S. Brind and R. McKenzie (eds.) The State of the Real: Aesthetics in the Digital Age, London: I.B. Tauris \& Co.

VIBE Books (2001) Hip-hop Divas, London: Plexus.

Village Voice (2007) 30.10.2007 Issue. Available from: http://www.villagevoice.com/2007-10-30/music/shooting-star/full/ [accessed 07.09.2011].

Wang, O. (2006) 'Trapped in Between the Lines. The aesthetics of Hip-hop Journalism', in J. Chang (ed.) Total Chaos. The Art and Aesthetics of Hip-hop, New York: Basic Civitas.

\section{Biography}

My research interests lie in the field of hip-hop culture and gender studies. I was recently awarded a PhD at London South Bank University where I investigated the written portrayal of hip-hop female performative identities in hip-hop journalism. My future research plans are to build on the foundations of my $\mathrm{PhD}$ to provide women in hip-hop with alternative paths to make sense of our engagement with the culture, and to pursue a career as an academic. I am currently employed as a Media Manager at MediaCom London, where I work full-time to strategically plan, implement and analyse advertising campaigns for a portfolio of clients. I can be contacted at barbiebabe@ libero.it. 